\title{
(Mobile Assisted Language Learning) MALL Implementation During Distance Learning
}

\author{
Febriyanti, M.E ${ }^{1 *}$, Putra, I.N.A.J ${ }^{2}$, Santosa, M.S ${ }^{3}$ ID \\ ${ }^{1,2,3}$ English Language Education, Ganesha University of Education, Singaraja, Indonesia
} *Corresponding author: erwindafebriyanti.ef@gmail.com

\section{Abstrak}

Aturan belajar dari rumah sudah diterapkan sejak merebaknya Virus Corona. Hal ini berdampak pada sektor pendidikan di Indonesia yang membuat pemerintah membuat regulasi untuk belajar dari rumah-selain itu, membuat proses belajar mengajar diadakan dalam konteks pembelajaran jarak jauh. Penelitian ini bertujuan untuk menganalisis proses pembelajaran yang menerapkan MALL selama proses pembelajaran jarak jauh dan tantangan selama pendidikan. Instrumen yang digunakan untuk memperoleh data adalah kuesioner self-rated, daftar periksa observasi, dan pedoman wawancara. Instrumen ini dikembangkan dari Alat Penilaian Kemampuan Calon Guru (APKCG) dan kerangka desain pembelajaran RASE. Teknik analisis data yang digunakan adalah analisis deskriptif kualitatif. Studi ini menunjukkan bahwa guru bahasa Inggris telah menerapkan MALL selama proses pembelajaran jarak jauh dengan menggunakan beberapa platform online sebagai ruang kelas dalam aktivitasnya. Beberapa tantangan muncul dari guru dan siswa dalam proses pembelajaran ini, antara lain kurangnya kemampuan guru dalam memanfaatkan teknologi, perangkat siswa yang tidak mendukung, dan koneksi siswa yang tidak stabil.

Kata kunci: Pembelajaran Seluler, MALL, Pembelajaran Jarak Jauh

\section{Abstract}

The rules for studying from home have been implemented since the outbreak of the Corona Virus. This impacts the education sector in Indonesia, which makes the government make regulations to learn from home - in addition, making the teaching and learning process held in the context of distance learning. This study aims to analyze the learning process that applies MALL during the distance learning process and the challenges during education. The instruments used to obtain the data were self-rated questionnaires, observation checklists, and interview guidelines. This instrument was developed from the Prospective Teacher Ability Assessment Tool (APKCG) and the RASE learning design framework. The technique used to analyze the data is descriptive qualitative analysis. This study indicates that English teachers have implemented MALL during the distance learning process by using several online platforms as classrooms in their activities. Several challenges arise from teachers and students in this learning process, including the lack of teacher ability in utilizing technology, unsupported student devices, and unstable student connections.

Keywords: Mobile Learning, MALL, Remote Learning

$\begin{array}{ll}\text { History: } & \text { Publisher: Undiksha Press } \\ \text { Received : February 06, 2021 } & \text { Licensed: This work is licensed under } \\ \text { Revised : February 09, 2021 } & \text { a Creative Commons Attribution 3.0 License } \\ \text { Accepted : March 26, 2021 } & \text { PC () O }\end{array}$

\section{Introduction}

The rapid development of the digital era has affected all sectors in human daily life, including education sector. This era makes the education field integrated with the immense use of mobile technology. The technology helped both teachers and student in the process of teaching and learning (Nursyam, 2019; Warsita, 2017). It assists the teacher to find out various sources to create learning material and share it with the students. There are some kind of mobile technologies that are able to use in the language teaching, for instance, smartphone, mp3/mp4, Ipod, and electronic dictionaries (Geng, Law, \& Niu, 2019; G. Z. Liu, Lu, \& Lai, 2016). Hence, the use of mobile technology in the teachin and learning process need to be considered in order to make the process of learning is meaningfull and effective (Noviar, 2016; Sunismi, 2015). In the current situation, where the world has faced the virus outbreak there was a change in most people daily routine's life. As announced by WHO, this condition 
is a global health emergency that impacts all sectors in every country, including the education field. According to UNESCO in2020, there were 193 countries that closed their school by 23 April 2020 that affecting 1.6 billion students all over the world (Fund, 2020).

Since the virus outbreak, governments around the world, including Indonesia, created a regulation to shut down all of the schools (Fitriyani, Fauzi, \& Sari, 2020; Wahyono, Husamah, \& Budi, 2020). This regulation significantly affected school activities, teachers need to find out a new regulation to conduct the teaching and learning process during this period. The activities that are suggested by the government in order to keep the learning process going are to conduct a teaching process by implementing online learning for those who have internet access and create an innovative learning process for those who do not have any internet access (Ariebowo, 2021; Atmojo \& Nugroho, 2020; Ayuni, Marini, Fauziddin, \& Pahrul, 2021). According to the letter of Indonesian Ministry of Education and Culture (MOEC) No. 15 in 2020 about the guidelines of study from home in the emergency of the spread of Corona Virus Diseases (COVID-19), teachers and students are not allowed to go to school as an effort to stop the chains of spreading process of the corona virus (Abidah, et al., 2020; Wulandari \& Purwanta, 2021). One of the important principles of study from home is the flexibility of school's activities and assignments that can be changed based on the situation in each region while considering the facilities available for teachers and students. This flexible regulation enables the teachers to have choices whether it is possible for the students to receive a learning process using mobile technology or not.

In Indonesia, remote learning, also known as distance learning, has been a common thing for higher education since 8 years ago (Arifuddin, Suwatra, \& Mahadewi, 2020; Pratiwi, Suartama, \& Tegeh, 2016; Wulandari, Sudatha, \& Simamora, 2020). It has been implemented since the Indonesian Ministry of Education and Culture. Since this regulation is only for higher education, the current situation makes the regulation needs to be adapted in all levels of education from the level of elementary school to senior high school. In many schools, the implementation of mobile learning is not a familiar thing to teachers, especially for those who are categorized as digital immigrants (Cecep, Mutaqin, \& Pamungkas, 2019; Muswita, Utomo, Yelianti, \& Wicaksana, 2018; Sunismi, 2015). Furthermore, elementary and junior high school students are also still unfamiliar with this implementation of mobile learning as in this stage, most of them have not yet owned mobile phones (Irni, Sumarni, \& Saraswati, 2017; Suryanda, Ernawati, \& Maulana, 2016). It gives the government as well as the teachers some challenges in this unexpected situation. The biggest challenge of remote learning is the fact most of the students in junior high school do not have the supported devices in order to access the learning. Due to this problem, the head of Education, Youth, and Sport of Buleleng regency announced that the teachers are obligated to help the students who do not have supported devices by giving them smartphones.

Mobile assisted language learning (MALL) is one of the tools that support the teaching and learning process during the implementation of learning from home. It helps the teacher and their students to conduct learning activities anytime and anywhere without going to school and meet others (Irwanto, et al., 2019; Ngabekti, et al., 2019). The use of a mobile phone to support teaching and learning activities, especially in the English language context has been implemented in many schools across the country (C.-H. Chen \& Tsai, 2021; C. Liu et al., 2021). There are several mobile devices that assist students' language learning, for example, mobile phone, smartphone, iPods, $\mathrm{mp} 3 / \mathrm{mp} 4$ players, and electronic dictionaries $(\mathrm{G}$. Z. Liu et al., 2016). Mobile phones are able to assist and support the students in learning English language (Yudhiantara \& Saehu, 2017). Mobile phone is an effective tool for students to help them improve their language. Moreover, the implementation of mobile phones in Junior high school is still considered uncommon in several junior high schools in Bali specifically in the Buleleng region. 
The implementation of MALL in formal learning and classroom setting has been enormously studied, but the study in remote learning context is very rare to find especially, at the junior high school level (Y. Chen, Mayall, York, \& Smith, 2019; Hou \& Aryadoust, 2021). In the context of online learning during emergency remote learning, the teachers employed MALL and used several applications and platforms in order to conduct learning activities (Atmojo \& Nugroho, 2020; Soleimani, Ismail, \& Mustaffa, 2014). The applications and platforms that widely used over online learning were Google Classroom, Zoom, Whatsapp, Schoology, Autodesk SketchBook, TEDED, FastStone, Capture, Google Forms, Quizizz, Kahoot, and Youtube (Atmojo \& Nugroho, 2020; Segaran, Ali, \& Hoe, 2014). Students, teachers, and students' parents faced some obstacles in the remote learning activities (Atmojo \& Nugroho, 2020). The common obstacles found by the students were lack of smartphone ownership, unstable internet connection due to their home location, and lack of awareness of online learning. Moreover, teachers also found some challenges the difficulty of creating materials that are appropriate for the students that have various levels of cognitive, the difficulty of giving feedback because of the time allotment from school policy was not enough, and the lack of students' awareness to respond to the teacher's instruction using English.

The findings of previous research also stated that there were internal and external problems found in the implementation of MALL during the pandemic situation (Saragih \& Jaelani, 2020). The findings of previous studies also stated that Mobile Assisted Language Learning (MALL) could help students in learning (Azar \& Nasiri, 2014; Dashtestani, 2013; Yudhiantara \& Saehu, 2017). There is no study on the implementation of MALL during distance learning. This study aims to analyze the performance of MALL during distance learning. It is hoped that MALL can help students in distance learning.

\section{Methods}

The overall arrangement of this current study was conducted based on the implementation of a case study research design. The case study research design is a frame within qualitative research approach which is focused on individual teachers, a classroom, or a school (Gay, Mills, \& Airasian, 2012). It is also often used when the researcher is trying to find out the characteristics, frequencies, trends, and categories in the research setting. This research design was employed in this current study as it was aimed to obtain the data in SMP Negeri 1 Gerokgak such as the implementation of MALL during remote learning context, the application used by the teacher in implementing MALL in remote learning context, the challenges faced during teaching and learning process in remote learning context, and the possible solutions by the English teacher in SMP Negeri 1 Gerokgak that can be done to prevent those challenges. Furthermore, the obtained data were analyzed qualitatively by preparing and organizing the obtained documents, pictures, and transcripts as the first step of the data analysis process. This current study also employed the concept of data triangulation by Miles et al., (2014) in which several related theories and previous studies about the implementation of MALL and remote learning were used to support the trustworthiness of this research.

The instruments of this current study were in form of a self-rated questionnaire, observation checklist, and interview guide. These three instruments were developed from Alat Penilaian Kemampuan Calon Guru (APKCG) Undiksha and RASE Learning Design Framework by Churchill et al.,(2016). APKCG is a benchmark for a pre-service teacher to prepare a teaching process. It helps the pre-service teacher or teacher to make effective, efficient, and meaningful learning for students. Preparing all materials needed is a step to improve the quality of the teaching process. According to APKCG Undiksha (IG, G, \& TL, 2019), there are three points that are needed to take into account before a pre-service teacher 
or teacher teaches the students. These three points are assessment instrument for a lesson plan, assessment instrument for teaching process, and assessment instrument for personality and social competence. In addition, RASE learning design framework merges the technology with the conventional teaching process (Churchill, King, \& Fox, 2013).

In this study, the self-rated questionnaire was used to gain the infromation about how the English teacher implementing the MALL in remote learning context in teachers' point of view and the application used by the English teachers. Meanwhile, the observation checklist was used to obtain the data from the researcher's point of view. Furthermore, the interview guide was used to gain data about the challenges faced by the English teacher and their solutions. The subject of this research were the English teachers in SMP Negeri 1 Gerokgak.

\section{Results and Discussion}

Based on the result of observation, MALL was used from the beginning until the end of the lesson. In terms of the beginning of the lesson, the teachers started opening the class by greeting the students and giving instruction to the students in WhatsApp Group. The teacher starts the class by greeting the students by saying good morning and check students' condition by asking how are you today and then reminded the students to fill the absence and study the material. The teacher shared the attendance link on Google Classroom. Figure 2 showed the list of attendance recapitulated by the teachers. The purpose of doing a recapitulation and sharing it on WhatsApp Group was to remind the students to fill the absence on the absence link and to check whether there were some students who were missing or not. After filling the absence, the students were asked to conduct a learning process based on the instruction given by the teacher on WhatsApp group and google classroom.

The material was put below the absence list to make students able to see the material and started studying the material. The teacher also gave instructions in the Google form to remind the students to study the material carefully. The material given by the teacher was in the form of the PPT. The content of the PPT was the generic structure of recount text and the example of the text as a guideline for the students if they need to make the assignment instructed by the teachers. The PPT was in two languages which are Bahasa Indonesia and English to make it easier for students to understand the material. The detail of the PPT was shown in Figure 1.

Based on the result of the self-rated questionnaire on the lesson plan. It was indicated that the teacher used problem-solving strategy in the teaching process. This result was supported by the lesson plan made by the teacher. In the whilst activity, the teacher implemented problem-solving strategy for the students. It can be seen in Figure 2. Next, the online platform was used by the students to submit their work and the teacher assessed the students' work and gave them grades. The grade and the students' assignment in the online platform. In Google Classroom, the teacher can monitor students' work such as checking who has not submitted the assignment by looking at the feature of student work in Google Classroom in which each student has a grade from 0-100 which was filled by the teacher after assessing students' work. The way how the teacher assesses the assignment can be seen in Figure 3. The assignment must be submitted in the form of a picture to make teachers easy to access the assignment because the teachers can zoom in and zoom out the picture to check the mistakes created by the students which are later commented on by the teachers in the discussion section. Because of that, the picture must be clear and in a high pixel in order to make the teachers able to see the assignment. 


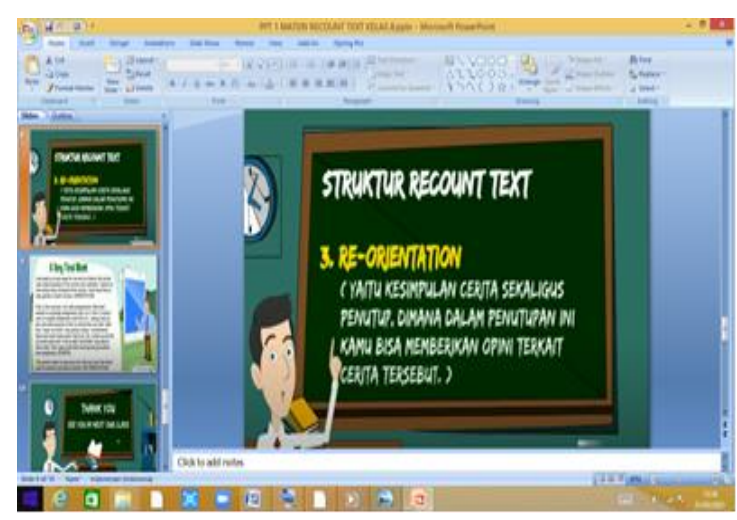

Figure 1. Detail of the PPT

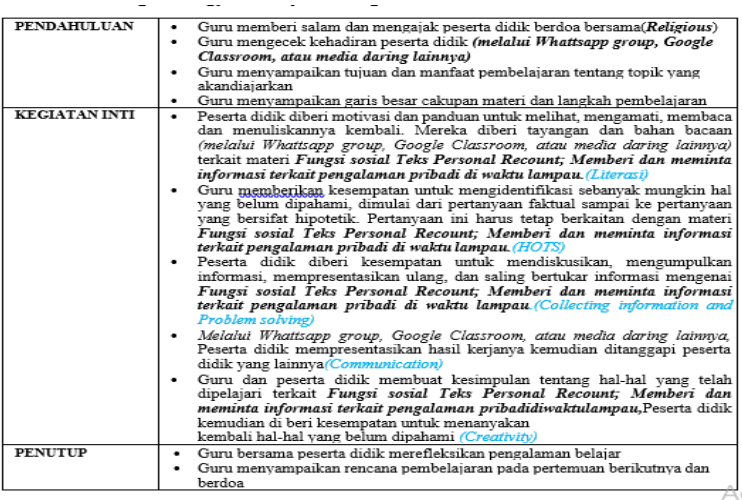

Figure 2. Teaching Strategy Used by The English Teacher

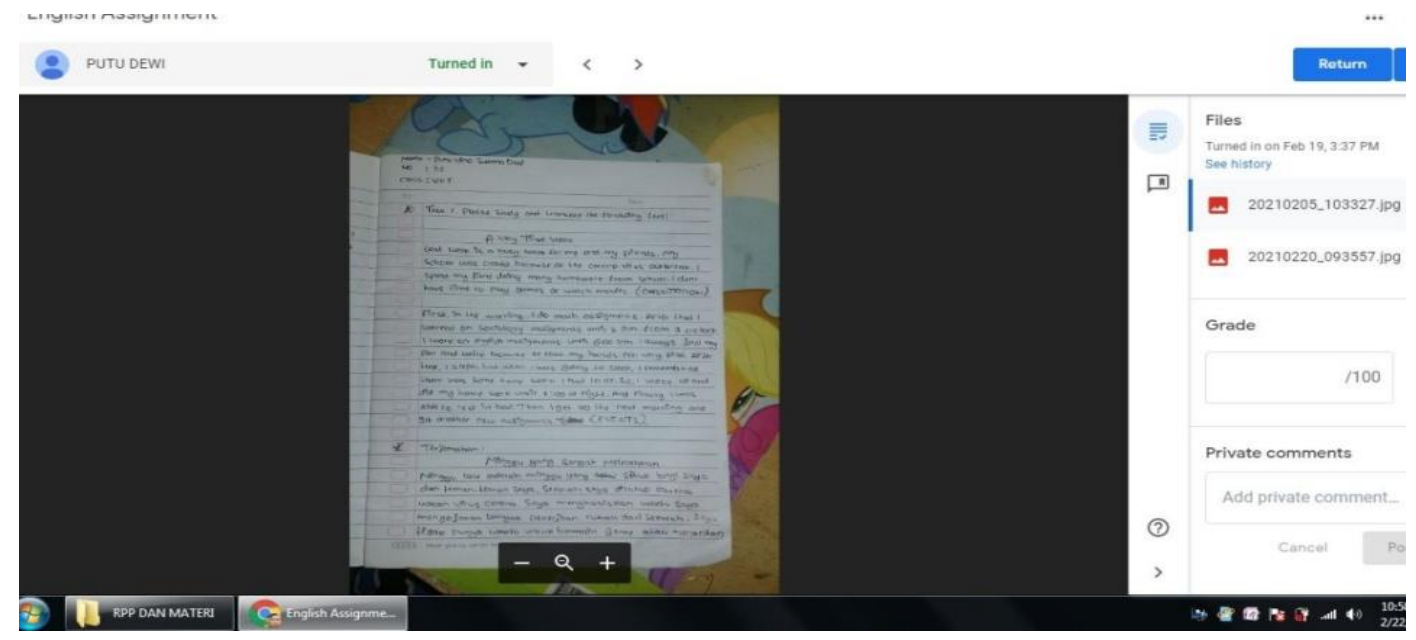

Figure 3. Assessing Assignment

During the activities in the online class, the teachers must keep the learning on track to make students focus on the lesson. The teachers led the students by giving instruction to the students and they must obey the instruction. The sample of the instruction can be seen in the quoted text below. "Om Swastiastu, anak-anak yang ibu sayangi, tugas ibu kirim lebih awal dari jadwal, mohon dikerjakan sesuai jawal, ikuti dulu pelajaran sesuai jadwal, jawaban dikirim di grup ini!" ("Om swastiastu, Dear children, I have sent the assignment earlier from the schedule. Please do it according to the schedule, follow the lesson according to the schedule, the answer will be sent in this group!"). Based on the quoted text, the teachers gave the instruction in the form of an imperative sentence along with exclamation mark (!) to make it serious in order to make students obey the instruction from the teacher. The teacher also gave the screenshot of the assignment to make students believe if the assignment existed in the class and the students then checked the assignment and start making it. To conclude, an online platform as MALL was used to open the class, to give assignments and conduct discussions as core activities in the class, and to assess students' work.

Based on the result of the interview session, there were two challenges faced by the English teacher. First, how to improve students' motivation on joining the online class. The students had some reasons why they did not join the online learning, and preferred to receive the material that was given by the teacher to their home as well as submit the assignment given by the teacher directly to the school. For instance, one of the reasons was because they had unstable and no internet connection. The second challenge was the teachers' lack of 
ability in operating online learning because of their unfamiliarity with using technology in the teaching process. The interview result can be seen below.

Teacher 1: ("The challenge that I faced coming from the students. The students only have internet packages for chatting in WhatsApp group, while I provide the material for students in Google Classroom and another LMS. For students who did not have internet packages and supported devices, we need to deliver the material to them once a week to their house and the students submit the task to the school if they had homework. But, the sources that I give were different from the sources in online learning. For example, in online learning, I provided the students with a video, but for the students who cannot join the online class, I only sent them a text."). Teacher 2: ("I faced a challenge in operating device on online learning. Because I am old, I cannot keep up with the technology. So I only share the material that I have made to WhatsApp group."').

Teacher 3: ("First of all, the most challenges that I face are coming from the students. In the first, the students were actually given internet packages to access online learning, but the students still found obstacles because they have unsupported devices. It might be because the lack of students' motivation in joining the online class, so they had so many reasons to not join the class. Besides, there were several students that could not join the online class because they helped their parents to work. But from $100 \%$ of students, there were only $25 \%$ of students that cannot join the online classes. So, when we as a teacher had a schedule in teaching and sharing the material in online learning platform and asked the students to fill the class attendance for example at 1 p.m they have to finish reading the material and fill the class attendance, the teacher cannot force the students to study and fill the attendance at that time because some of the students only have an access to open the learning system management in the evening. So, we need to be flexible."). In addition, there was a challenge of the MALL faced by the student when she tried to log in to the system. There was a bug in the system that made the student unable to log in. The student informed the teacher about the bug and the teacher gave suggestions to help the students log in.

\section{Discussion}

Referred from the finding section, it can be implied that the English teachers in SMP Negeri 1 Gerokgak implemented MALL in accordance with the implementation of RASE learning design framework which has four important components as Resource, Activity, Support, and Evaluation. The theory stated that those four elements are very essential in conducting remote learning with the integration of MALL in which the English teachers in SMP Negeri 1 Gerokgak follow the pattern by integrating those elements in their remote learning process.

Based on the opening session, it shows that the teacher in SMP Negeri 1 Gerokgak had implemented MALL to open the learning process by greeting the students, reminding the students to fill the students' attendance, and asking them to study the resource that had been given in the Google classroom. During the remote learning situation, the teachers have to prepare the material and upload it to the platform that has been concurred. Preparation of material before this lesson will help students learn first (Gafur, 2012; Pratama, Firman, \& Neviyarni, 2019; Puspita, 2019). By doing such things, it means that the teacher gave support in the form of a platform used in delivering material and greeting the students. It indicates that the teacher has taken the rule as the leader of the remote learning process by creating a room in form of an online platform as a virtual classroom where the whole remote learning process took place. As the result, it will be easier for the students to join the learning process as they have already have given instructions to use the asked online platform. It also means that the teacher already provides support in form of a "place" for students to conduct the learning process. It can be said that the teacher implemented MALL in accordance with the 
implementation of RASE learning Design Framework especially the support element. Support is related to the platform that can facilitate the students to ask about the lesson and have a chat with the other students and teacher in order to discuss the assignment or obstacles that the students might find during the lesson (Churchill et al., 2013; Kurtz, Tsimerman, \& Steiner, 2014; Solehana, Asrori, \& Usman, 2019).

In addition, the teacher gave resources in the form of slide PPT to the students during the learning process. The teacher tended to share a power point as the course material with the students than share a video because a power point was less in spending the internet quota of the students (Bhuana \& Apriliyanti, 2020; Masyithah, Muchtar, \& Mahmud, 2015; Yulisari, 2013). It also in coherence with the theory of RASE about resources which are associated with content, material, and lecture by the teacher in the teaching process. The use of media in learning can help students understand learning materials (Gunarta, 2018; Putri \& Desyandari, 2019; Tafonao, 2018). The teacher put the material below the students' attendance and asked the students to learn carefully. The material that was put on the online platform was in the form of PPT. The detail of the PPT can be seen in Figure 2. In this PPT, the teacher explained the generic structure of the Recount text. The explanation was in Bahasa Indonesia and English. The teacher used two languages in order to make the students understand the content easily. Moreover, by providing those materials in the form of PPT contained with appropriate content needed by the students and place it visibly in the virtual classroom that already known by the students as it is used in the greeting and checking attendance process, it can be said that the teacher had already integrated MALL in a remote learning process by considering the RASE learning Design Framework especially the resource elements that can support the students to fully understand the lesson.

Some teachers had implemented MALL during remote learning in a great way. Even so, there was still a teacher who could not implement MALL well. The challenges that found by the researcher during the implementation of MALL in remote learning were coming from both the teacher and students. It is in line with the RASE theory which mentioned that the four elements are important in implementing MALL during remote learning. Thus, if one of those elements was not completed, it will become a problem or challenge for both teacher and students. From the teacher itself the implementation of MALL was a new activity. The teacher could not catch up with the technology used even though, the teacher had experienced this situation for more than a year and it led the teacher to made material offline and sent it to WhatsApp. It was because the teachers were not familiar with the digital technology and they felt it was complicated to learn how to operate technology while they do not have ability to create a learning environment using MALL.

EFL teachers faced a challenge that they did not familiar with the use of online platform to conduct an online learning in remote learning context (Nugroho, Ilmiani, \& Rekha, 2021). This is also by previous research, which states that one of the challenges of English in implementing mobile learning is the competence of teachers in operating technology (Rosalina, Nasrullah, \& Elyani, 2020). There was a pedagogical challenge in which the teacher faced that they were lack of digital skill during the process remote learning (Ferri et al., 2020). It also was related to the previous study in Iranian EFL teachers context that the teacher had no required skill to develop or use MALL (Dashtestani, 2013). Meanwhile, the challenges that were coming from the students were the lack of internet connection and they have unsupported devices to use during remote learning process. It was one of the big challenges faced during the implementation of MALL since the uppermost tool to conduct MALL is supported devices. From the challenges above, one of the solutions given by the English teacher to the students who had no internet connection and supported devices were delivered the material to the students' house once a week. But, before that, the students were asked to fill the form of offline learning where the students informed the 
teacher about the reasons why they did not join the online class. Even though the material given to the students who committed to do offline learning was different from online learning, this is the best solution in order to make the students had an opportunity to learn during the remote learning context.

\section{Conclusion}

Based on the result of the study, it can be concluded that the English teachers in SMP Negeri 1 Gerokgak had implemented MALL in their teaching and learning process during remote learning context, yet there were still some challenges that the teachers found during the teaching process. Furthermore, the challenges were coming from both English teachers and students.

\section{References}

Abidah, A., Hidaayatullaah, H. N., Simamora, R. M., Fehabutar, D., \& Mutakinati, L. (2020). The Impact of Covid-19 to Indonesian Education and Its Relation to the Philosophy of "Merdeka Belajar." Studies in Philosophy of Science and Education, 1(1), 38-49. https://doi.org/https://doi.org/10.46627/sipose.v1i1.9.

Ariebowo, T. (2021). Autonomous learning during COVID-19 pandemic: Students ' objectives and preferences. Journal of Foreign Language Teaching and Learning, 6(1), 56-77. https://doi.org/https://doi.org/10.18196/ftl.v6i1.10079.

Arifuddin, Suwatra, \& Mahadewi. (2020). Pengembangan Konten E-learning Berorientasi Pendidikan Karakter Pada Mata Pelajaran Seni Budaya. Jurnal Edutech Undiksha, 8(2). https://doi.org/http://dx.doi.org/10.23887/jeu.v8i2.28942.

Atmojo, A. E. P., \& Nugroho, A. (2020). EFL classes must go online! Teaching activities and challenges during COVID-19 pandemic in Indonesia. Register Journal, 13(1), 49-76. https://doi.org/https://doi.org/10.18326/rgt.v13i1.49-76.

Ayuni, D., Marini, T., Fauziddin, M., \& Pahrul, Y. (2021). Kesiapan Guru TK Menghadapi Pembelajaran Daring Masa Pandemi Covid-19. Jurnal Obsesi : Jurnal Pendidikan Anak Usia Dini, 5(1). https://doi.org/https://doi.org/10.31004/obsesi.v5i1.579.

Azar, A. S., \& Nasiri, H. (2014). Learners' Attitudes toward the Effectiveness of Mobile Assisted Language Learning (MALL) in L2 Listening Comprehension. Procedia Social and Behavioral Sciences, 98. https://doi.org/https://doi.org/10.1016/j.sbspro.2014.03.613.

Bhuana, G. P., \& Apriliyanti, D. L. (2020). Teachers' Encounter of Online Learning: Challenges and Support System. 5(52), 147-158.

Cecep, Mutaqin, \& Pamungkas. (2019). Pengembangan Modul Quick Math Berbasis Mobile Learning sebagai Penunjang Pembelajaran Matematika di SMA. Prisma Sains: Jurnal Pengkajian Ilmu Dan Pembelajaran Matematika Dan IPA IKIP Mataram, 7(2). https://doi.org/https://doi.org/10.33394/j-ps.v0i0.1761.

Chen, C.-H., \& Tsai, C.-C. (2021). In-service teachers' conceptions of mobile technologyintegrated instruction: Tendency towards student-centered learning. Computers \& Education, 170(1). https://doi.org/https://doi.org/10.1016/j.compedu.2021.104224.

Chen, Y., Mayall, H. J., York, C. S., \& Smith, T. J. (2019). Parental perception and English Learners' mobile-assisted language learning: An ethnographic case study from a technology-based Funds of Knowledge approach. Learning, Culture and Social Interaction, 22. https://doi.org/https://doi.org/10.1016/j.lcsi.2019.100325.

Churchill, D., King, M., \& Fox, B. (2013). Learning design for science education in the 21st century. Zbornik Instituta Za Pedagoska Istrazivanja, 45(2), 404-421. https://doi.org/10.2298/ZIPI1302404C. 
Churchill, D., King, M., \& Fox, B. (2016). Framework for Designing Mobile Learning Environments Daniel. Mobile Learning Design: Theories and Application, 3-22. https://doi.org/10.1007/978-981-10-0027-0.

Dashtestani, R. (2013). Implementing mobile-assisted language learning (MALL) in an EFL context: Iranian EFL teachers' perspectives on challenges and affordances. The JALT CALL Journal, 9(2), 149-168. https://doi.org/10.29140/jaltcall.v9n2.153.

Dewi, A., Ningrum, H., \& Arrasyid, F. I. (2021). Students 'Perceptions Towards The Implementation Of Mall In English Learning: A Case In Senior High School. 2(1), 21-32. https://doi.org/10.22236/ellter.v2i1.6243.

Ferri, F., Grifoni, P., \& Guzzo, T. (2020). Online Learning and Emergency Remote Teaching: Opportunities and Challenges in Emergency Situations. Societies, 10(4), 86. https://doi.org/10.3390/soc10040086.

Fitriyani, Y., Fauzi, I., \& Sari, M. Z. (2020). Motivasi Belajar Mahasiswa Pada Pembelajaran Daring Selama Pandemik Covid-19. Profesi Pendidikan Dasar, 7(1), 121-132. https://doi.org/10.23917/ppd.v7i1.10973.

Fund, U. N. C. (2020). COVID-19 and Children in Indonesia. COVID-19 and Children in Indonesia, (11 May).

Gafur, A. (2012). Desain Pembelajaran Konsep, Model, dan Aplikasinya dalam Perencanaan Pelaksanaan Pembelajaran. Yogyakarta: Penerbit Ombak.

Gay, L. R., Mills, G. E., \& Airasian, P. W. (2012). Educational Research: Competencies for Analysis and Application.

Geng, S., Law, K. M. Y., \& Niu, B. (2019). Investigating self-directed learning and technology readiness in blending learning environment. International Journal of Educational Technology in Higher Education, 16(1), 17. https://doi.org/10.1186/s41239-019-0147-0.

Gunarta, I. G. (2018). Pengaruh Model Pembelajaran TGT Berbantuan Media Question Card Terhadap Hasil Belajar IPA. Jurnal Pedagogi Dan Pembelajaran, 1(2). https://doi.org/http://dx.doi.org/10.23887/jp2.v1i2.19338.

Hou, Z., \& Aryadoust, V. (2021). A review of the methodological quality of quantitative mobile-assisted language learning research. System, 100. https://doi.org/https://doi.org/10.1016/j.system.2021.102568.

IG, B., G, M., \& TL, T. (2019). Universitas Pendidikan Ganesha. Jurnal IKA, 17(2), 171. https://doi.org/10.23887/ika.v17i2.19853.

Irni, Sumarni, \& Saraswati. (2017). Pengembangan Media Pembelajaran Mobile Learning Berbasis Android. Jurnal Penelitian \& Pengembangan Pendidikan Fisika, 3(1), 59. https://doi.org/10.21009/jrpk.072.10.

Irwanto, Taufik, Hernawan, \& Rizal. (2019). Efektivitas Multimedia Interaktif Dan Mobile Learning Dalam Meningkatkan Hasil Belajar Siswa Pada Mata Pelajaran Seni Budaya. Jurnal Pendidikan Dan Kajian Seni, 4(1). https://doi.org/http://dx.doi.org/10.30870/jpks.v4i1.6845.

Kurtz, G., Tsimerman, A., \& Steiner, O. (2014). The Flipped Classroom Answer to Future Learning? European Journal of Open, Distance and E-Learning, 17(2). https://doi.org/https://doi.org/10.2478/eurodl-2014-0027.

Liu, C., He, J., Ding, C., Fan, X., Hwang, G.-J., \& Zhang, Y. (2021). Self-oriented learning perfectionism and English learning burnout among EFL learners .using mobile applications: The mediating roles of English learning anxiety and grit. Learning and Individual https://doi.org/https://doi.org/10.1016/j.lindif.2021.102011.

Liu, G. Z., Lu, H. C., \& Lai, C. T. (2016). Towards the construction of a field: The developments and implications of mobile assisted language learning (MALL). Digital 
Scholarship in the Humanities, 31(1), 164-180. https://doi.org/10.1093/llc/fqu070.

Masyithah, H., Muchtar, Z., \& Mahmud. (2015). Pengaruh Penerapan Multimedia Camtasia Studio dan Media Power Point terhadap Aktivitas dan Hasil Belajar Siswa pada Materi Struktur Atom. Jurnal Pelangi Pendidikan, 8(2). https://doi.org/https://doi.org/10.24114/pelangi.v22i2.6217.

Miles, M. B., Huberman, A. M., \& Saldana, J. (2014). Qualitative Data Analysis.

Muswita, Utomo, A. B., Yelianti, U., \& Wicaksana, E. J. (2018). Pengembangan E-Book Berbasis Mobile Learning Pada Mata Kuliah Struktur Tumbuhan. Pendidikan Biologi, 11, 93-104. https://doi.org/https://doi.org/10.20961/bioedukasi-uns.v11i2.23814.

Ngabekti, Prasetyo, Hardianti, \& Teampanpong. (2019). The Development of STEM Mobile Learning Package Ekosistem. Jurnal Pendidikan IPA Indonesia, 8(1), 81-88. https://doi.org/https://doi.org/10.15294/jpii.v8i1.16905.

Noviar, D. (2016). Pengembangan Ensiklopedi Biologi Mobile Berbasis Android Materi Pokok Pteridophyta Dalam Rangka Implementasi Kurikulum 2013. Cakrawala Pendidikan, 35(2). https://doi.org/https://doi.org/10.21831/cp.v15i2.8255.

Nugroho, A., Ilmiani, D., \& Rekha, A. (2021). EFL Teachers' Challenges and Insights of Online Teaching amidst Global Pandemic. Metathesis: Journal of English Language, Literature, and Teaching, 4(3), 277. https://doi.org/10.31002/metathesis.v4i3.3195.

Nursyam, A. (2019). Peningkatan Minat Belajar Siswa Melalui Media Pembelajaran Berbasis Teknologi Informasi. Jurnal Penelitian Hukum Dan Pendidikan, 18(1), 811-819. https://doi.org/http://dx.doi.org/10.30863/ekspose.v18i1.371.

Pratama, F., Firman, \& Neviyarni. (2019). Pengaruh Motivasi Belajar IPA Siswa Terhadap Hasil Belajar Di Sekolah Dasar Negeri 01. Jurnal Ilmu Pendidikan, 1(3), 280-286. https://doi.org/https://doi.org/10.31004/edukatif.v1i3.63.

Pratiwi, I., Suartama, I. K., \& Tegeh, I. M. (2016). Pengembangan E-Learning dengan Model Prototype Berorientasi Model Pembelajaran Inquiry Siswa Kelas VII SMPN 2 $\begin{array}{llll}\text { Negara. Jurnal Edutech } & \text { Undiksha, }\end{array}$ https://doi.org/http://dx.doi.org/10.23887/jeu.v4i2.7615.

Puspita, L. (2019). Pengembangan Modul Berbasis Keterampilan Proses Sains Sebagai Bahan Ajar Dalam Pembelajaran Biologi. Jurnal Inovasi Pendidikan IPA, 5(1), 7987. https://doi.org/https://doi.org/10.21831/jipi.v5i1.22530.

Putri, E. N. D., \& Desyandari. (2019). Penggunaan Media Lagu Dalam Pembelajaran Tematik di Sekolah Dasar. Jurnal Ilmu Pendidikan, 1(3), 233-236. https://doi.org/https://doi.org/10.31004/edukatif.v1i3.52.

Rosalina, E., Nasrullah, \& Elyani, E. P. (2020). LET: Linguistics, Literature and English Teaching Journal The Analysis Of Difficulties. 9(2), 112-132.

Saragih, E. E., \& Jaelani, A. (2020). Implementing Mobile-Assisted Language Learning (MALL) in Writing Classroom: Pre-service Teacher's Opinions. Prosiding Lppm Uika Bogor, 24-33.

Segaran, K., Ali, A. Z. M., \& Hoe, T. W. (2014). Usability and User Satisfaction of 3D Talking-head Mobile Assisted Language Learning (MALL) App for Non-native Speakers. Procedia - Social and Behavioral Sciences, 131. https://doi.org/https://doi.org/10.1016/j.sbspro.2014.04.069.

Solehana, L., Asrori, A., \& Usman, A. (2019). The Development of E-Learning Teaching Material Based on Edmodo on Basic Competencies of National Integration at Class X of Senior High School. Journal Of Education, Teaching And Learning, 4(2). https://doi.org/https://doi.org/10.26737/jetl.v4i2.1914.

Soleimani, E., Ismail, K., \& Mustaffa, R. (2014). The Acceptance of Mobile Assisted Language Learning (MALL) among Post Graduate ESL Students in UKM. Procedia Social and .Behavioral Sciences, 118. 
https://doi.org/https://doi.org/10.1016/j.sbspro.2014.02.062.

Sunismi. (2015). Developing Guided Discovery Learning Materials Using Mathematics Mobile Learning Application As An Alternative Media For The Students Calculus II. Cakrawala Pendidikan, 34(5). https://doi.org/https://doi.org/10.21831/cp.v3i3.7340.

Suryanda, Ernawati, \& Maulana. (2016). Pengembangan Modul Multimedia Mobile Learning Dengan Android Studio 4.1 Materi Keanekaragaman Hayati Bagi Siswa Sma Kelas X. Jurnal Pendidikan Biologi, 9(1), 55-64. https://doi.org/https://doi.org/10.21009/biosferjpb.9-1.9.

Tafonao, T. (2018). Peranan Media Pembelajaran Dalam Meningkatkan Minat Belajar Mahasiswa. Jurnal Komunikasi Pendidikan, 2(2), 1-13. https://doi.org/https://doi.org/10.32585/jkp.v2i2.113.

Wahyono, P., Husamah, H., \& Budi, A. S. (2020). Guru profesional di masa pandemi COVID-19: Review implementasi, tantangan, dan solusi pembelajaran daring. Jurnal Pendidikan Profesi Guru, 1(1), 51-65. https://doi.org/https://doi.org/10.22219/jppg.v1i1.12462.

Wahyu, H., Cholis, N., Fauziati, E., \& Supriyadi, S. (2018). the Implementation of Mall in Reading Comprehension: Students ' Perspectives. The International English Language Teachers and Lecturers Conference (INELTAL), 36-42.

Warsita, B. (2017). Peran dan Tantangan Profesi Pengembang Teknologi Pembelajaran Pada Pembelajaran Abad 21. Kwangsan: Jurnal Teknologi Pendidikan, 5(2). https://doi.org/https://doi.org/10.31800/jtp.kw.v5n2.p77--90.

Wulandari, H., \& Purwanta, E. (2021). Pencapaian Perkembangan Anak Usia Dini di Taman Kanak-kanak selama Pembelajaran Daring di Masa Pandemi Covid-19. Jurnal Obsesi : Jurnal Pendidikan Anak Usia Dini, 5(1). https://doi.org/https://doi.org/10.31004/obsesi.v5i1.626.

Wulandari, Sudatha, \& Simamora. (2020). Pengembangan Pembelajaran Blended Pada Mata Kuliah Ahara Yoga Semester II di IHDN Denpasar. Jurnal Edutech Undiksha, 8(1), 1-15. https://doi.org/http://dx.doi.org/10.23887/jeu.v8i1.26459.

Yudhiantara, R. A., \& Saehu, A. (2017). Mobile-Assisted Language Learning (MALL) in Indonesian Islamic Higher Education. IJELTAL (Indonesian Journal of English Language Teaching and Applied Linguistics), 2(1), 21-31. https://doi.org/10.21093/ijeltal.v2i1.52.

Yulisari, S. (2013). Pengaruh Model Pembelajaran Vct Berbantuan Media Power Point Terhadap Hasil Belajar Pkn Siswa Kelas V Sd Gugus V Kecamatan Buleleng. Mimbar $P G S D$

Undiksha,

$1(1)$. https://doi.org/http://dx.doi.org/10.23887/jjpgsd.v1i1.719. 